\title{
Outcome of expectant line of management in early onset (24-32weeks) pregnancy induced hypertension
}

\author{
Krishna Mandade*, Kashika Singh, D. P. Bhavthankar
}

Department of Obstetrics and Gynecology, Pravara Medical College and Rural Hospital, Loni, Maharashtra, India

Received: 23 February 2017

Accepted: 27 March 2017

\author{
*Correspondence: \\ Dr. Krishna Mandade, \\ E-mail: kmandade@gmail.com
}

Copyright: () the author(s), publisher and licensee Medip Academy. This is an open-access article distributed under the terms of the Creative Commons Attribution Non-Commercial License, which permits unrestricted non-commercial use, distribution, and reproduction in any medium, provided the original work is properly cited.

\begin{abstract}
Background: Preeclampsia is a disease of multiple organ systems that is unique to pregnancy and is often associated with increased risk of maternal-perinatal adverse outcome, especially when it is severe and occurs well before term.

The objective of the study was to study expectant line of management in early onset pregnancy induced hypertension (24-32 weeks) and its maternal and perinatal outcome in relation to preterm delivery, IUD/ Still birth, and early neonatal deaths.

Methods: Total 100 patients presented with early onset pregnancy induced hypertension admitted in Pravara Medical College and Hospital. 50 patient's pregnancy terminated (Aggressive Group) depending on patients clinical profile and other 50 patients given expectant line of management and pregnancy was prolonged (Expectant Group). Maternal and perinatal outcome was compared between the two groups.

Results: No maternal mortality was seen in both groups.

Perinatal mortality in aggressive line of management was $54 \%$ while in expectant line of management perinatal mortality was $30 \%$. Neonatal deaths account for $24 \%$ in aggressive group and $10 \%$ in expectant group. Fetal survival rate in expectant group was $70 \%$ and in aggressive group it was $46 \%$.

Conclusions: Expectant management of severe preeclampsia at 24 to 32 weeks in a tertiary care center is associated with good perinatal outcome with a minimal risk for the mother.

The early use of antihypertensive drugs, optimum timing of delivery and strict fluid balance will help to achieve successful outcome.
\end{abstract}

Keywords: Expectant line, Preeclampsia, Perinatal outcome

\section{INTRODUCTION}

Preeclampsia is a disease of multiple organ systems that is unique to pregnancy and is often associated with increased risk of maternal-perinatal adverse outcome, especially when it is severe and occurs well before term. Pre-eclampsia is best described as pregnancy specific syndrome of reduced organ perfusion secondary to vasospasm and endothelial activation after 20th week of gestation and most frequently near term. It is a sort of immune response as foreign material i.e. father's genetic component tries to graft to mother with varying intensities of rejection. The term varying intensity is responsible for the numerous ways it presents in different pregnant women. Most often, it occurs in young women with first pregnancy. It is more common in twin pregnancies and in pregnancy induced hypertension in a previous pregnancy and also in women with preexisting chronic hypertension.

For many years, it was the practice that all the women with early onset pregnancy induced hypertension were delivered without delay. Approach for women with severe preeclampsia remote from term has been advocated by several investigators worldwide. This calls for "conservative" or "expectant" management with the 
aim of improving neonatal outcome without compromising maternal safety. Aspects of such management always include careful daily-and usually more frequent-impatient monitoring of the women and fetus, with or without antihypertensive drugs.

In one of the studies, Sibai and Memphis group attempted to prolong pregnancy because of fetal immaturity in 60 women with severe preeclampsia between 18 to 27 weeks. ${ }^{1}$ The result was disastrous. The perinatal mortality rate was $87 \%$. Although no mother died, 13 suffered placental abruption, 10 has eclampsia, 3 developed renal failure, 2 has hypertensive encephalopathy.

Because of these catastrophic outcomes, the Memphis group redefined their study criteria and performed a randomized trial of expectant versus aggressive management of 95 women who has severe preeclampsia but with more advance gestation of 28 to 32 weeks (sibai and associates 1994). ${ }^{1}$

Women with HELLP syndrome were excluded from this trial. Aggressive management included glucocorticoid administration for fetal lung maturation, followed by delivery in 48 hrs. Expectantly managed women were observed at bed rest and given either labetalol or nifedipine orally to control hypertension. In this study pregnancy was prolonged for a mean of 15.4 days in the expectant management group. An overall improvement in neonatal outcomes was also reported.

Barber and associates conducted a 10 year review of 3408 women with severe preeclampsia from 24 to 32 wks, they found that increasing length of antepartum hospital stays were associated with slight but significantly increased rates of maternal and neonatal mortality. $^{2}$

We also tried to study the difference in outcome of two different protocols for early onset preeclampsia and compared the results with existing studies so as to put forward the opinion on better protocol.

\section{METHODS}

Source of data: This is a prospective randomized observational study conducted on cases of early onset pregnancy induced hypertension that will be managed at Pravara Rural Hospital, a tertiary care and academic center from 2011 to 2013. One hundred women with pregnancy induced hypertension at 24-34wks fulfilling inclusion and exclusion criteria were enrolled. Demographic data involving age, parity, gestational age, any associated medical disorder and obstetric complication, clinical and laboratory findings were recorded in a preset proforma.

All the patients were subjected for ultrasonography for fetal wellbeing twice a week. Depending upon the clinical profile and the fetal wellbeing reports the decision of whether to terminate the pregnancy or to go for expectant line has decided. Mode of delivery, indications of cesarean section, fetal and maternal complications were observed.

The results observed were subjected to statistical analysis by appropriate test and a ' $p$ ' value of $<0.05$ was considered as significant.

The study was approved by ethical committee of rural medical college.

\section{Inclusion criteria}

All pregnant women between 24-32 weeks with moderate to severe pregnancy induced hypertension.

\section{Exclusion criteria}

- Patient with other medical complication along with pregnancy induced hypertension (Diabetes, Cardiac disease and liver disorder).

- HEELP as exclusion for expectant management.

\section{Management}

Initial assessment of the patient was done with detail history, examination, investigations and patients allocated in two protocols randomly. The decision of choosing management was based on clinical situation of the patient.

- In Medical management Antihypertensive medications like methyldopa, nifedipine and labetalol was given.

- Nifedipine dose-10 mg thrice daily, Methyldopa dose-250-500 thrice daily, Labetalol dose-100 mg BD.

- Corticosteroids were used routinely to accelerate fetal lung maturity in all cases where the gestational age was more than 25 weeks and less than 34 weeks i.e $24 \mathrm{mg}$ of betamethasone in two divided doses 24hrs apart.

- In Surgical management Depending on the condition of the patient methods like induction of labour and LSCS planned accordingly.

\section{Observations collected}

- Maternal outcome observed for known complications in intra and peri-partum period in terms of Abruption, uncontrolled HTN, retinal detachment, eclampsia, etc.

- Neonate is looked for its birth weight, APGAR, evidence of IUGR. Other signs are checked for sepsis, hyperbillirubinemia, respiratory distress syndrome and condition on discharge, variables. 


\section{RESULTS}

Table 1: Distribution of cases according to gravida score.

\begin{tabular}{|lll|}
\hline $\begin{array}{l}\text { Gravida } \\
\text { score }\end{array}$ & $\begin{array}{l}\text { Group I } \\
\text { (Aggressive) }(\mathrm{n}=50)\end{array}$ & $\begin{array}{l}\text { Group II } \\
(\text { Expectant })(\mathrm{n}=50)\end{array}$ \\
\hline Primi & $27(54 \%)$ & $26(52 \%)$ \\
\hline Multi & $23(46 \%)$ & $24(48 \%)$ \\
\hline Total & $\mathbf{5 0}$ & $\mathbf{5 0}$ \\
\hline
\end{tabular}

Table signifies the incidence of PIH is little bit on higher side in primi gravida patients than multi gravida but no significant association between gravida score and group I and II $(\mathrm{p}>0.05)$.

Table 2: Distribution of cases according to gestational age in weeks in Group I (aggressive) and Group II (expectant).

\begin{tabular}{|lll|}
\hline $\begin{array}{l}\text { Gestational } \\
\text { age in weeks }\end{array}$ & $\begin{array}{l}\text { Group I } \\
(\text { Aggressive })\end{array}$ & $\begin{array}{l}\text { Group II } \\
(\text { Expectant }) \\
(\mathbf{n = 5 0})\end{array}$ \\
\hline No. $(\%)$ & No. $(\%)$ \\
\hline 24-28 weeks & $14(28 \%)$ & $5(10 \%)$ \\
\hline 29-32 weeks & $36(72 \%)$ & $45(90 \%)$ \\
\hline Total & $\mathbf{5 0}$ & $\mathbf{5 0}$ \\
\hline
\end{tabular}

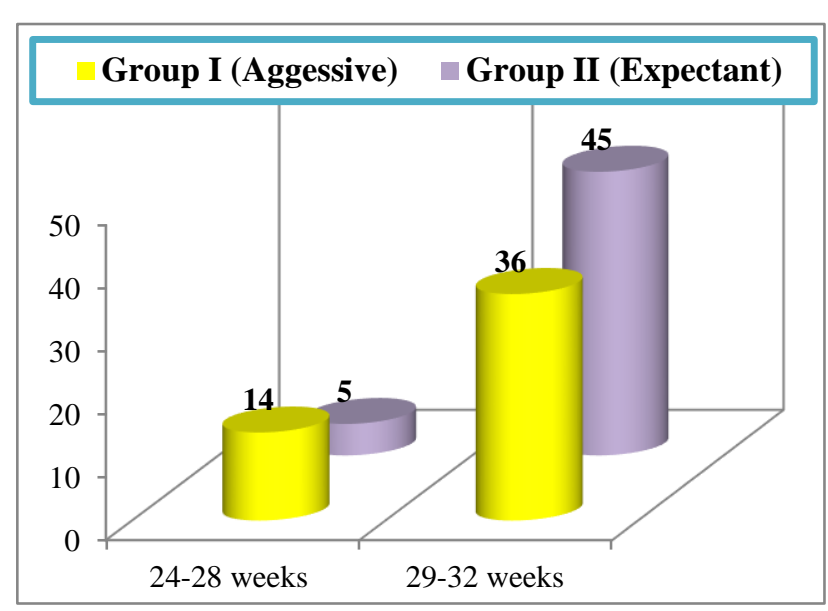

Figure 1: Distribution of cases according to gestational age in weeks in Group I (Aggressive) and Group II (Expectant).
Very few cases in very early onset severe preeclampsia treated with expectant line of management as fetomaternal morbidity is high at this gestational age where as we could take $90 \%$ of patients in his group above 28 wks.

Value of $X 2=5.263$, d.f. $=1, p=0.0218$.

By applying Chi-Square test there is a highly significant association between gestational age in group I and group II $(\mathrm{p}<0.01)$.

Table 3: Symptoms wise distribution of cases in Group I (Aggressive) and Group II (Expectant).

\begin{tabular}{|c|c|c|}
\hline \multirow[t]{2}{*}{ Symptoms } & $\begin{array}{l}\text { Group I } \\
\text { (Aggressive) } \\
(n=50)\end{array}$ & $\begin{array}{l}\text { Group II } \\
\text { (Expectant) } \\
(\mathbf{n}=\mathbf{5 0})\end{array}$ \\
\hline & No. (\%) & No. (\%) \\
\hline Ascitis, nausea & $1(2 \%)$ & 0 \\
\hline $\begin{array}{l}\text { Bleeding per } \\
\text { vagina }\end{array}$ & $1(2 \%)$ & 0 \\
\hline $\begin{array}{l}\text { Blurring, } \\
\text { nausea }\end{array}$ & $3(6 \%)$ & 0 \\
\hline Edema & $36(72 \%)$ & $37(74 \%)$ \\
\hline Headache & $4(8 \%)$ & 0 \\
\hline Vomiting & 0 & $1(2 \%)$ \\
\hline $\begin{array}{l}\text { No } \\
\text { complications }\end{array}$ & $5(10 \%)$ & $12(24 \%)$ \\
\hline Total & 50 & 50 \\
\hline
\end{tabular}

Edema was the most common symptom seen in expectant management group and in aggressive management besides edema other premonitory symptoms like blurring of vision, headache and ascitis were also seen. Total 5 in aggressive and 12 in expectant group have no symptoms.

By applying $\mathrm{Z}$ test of difference between two sample means there is a highly significant difference between mean values of all investigations in Group I and II $(\mathrm{p}<0.01)$ except Uric acid which is only significant $(\mathrm{p}<0.05)$. As $p t$ 's with normal PIH profile were kept for expectant line of management; derangement of profile occurred during the course and pregnancy was terminated in view of deranged profile.

Table 4: Distribution of cases according to investigations- in Group I (aggressive) and Group II (expectant).

\begin{tabular}{|llll|}
\hline Investigations & $\begin{array}{l}\text { Group I (Aggressive) }(\mathrm{n}=50) \\
\text { Mean } \pm \text { SD }\end{array}$ & $\begin{array}{l}\text { Group II (Expectant) } \\
\text { Mean } \pm \text { SD }\end{array}$ & $\begin{array}{l}\text { Z test value, } \\
\text { p value and significance }\end{array}$ \\
\hline Serum uric acid & $7.95 \pm 0.46$ & $5.68 \pm 1.01$ & $\begin{array}{l}\mathrm{Z}=14.46, \mathrm{p}<0.01, \\
\text { highly significant }\end{array}$ \\
\hline $\begin{array}{l}\text { Platelet count } \\
\text { PT (Prothrombin Time } \\
\text { in sec.) }\end{array}$ & $102250 \pm 22927.1$ & $182979.23 \pm 70869$ & $\begin{array}{l}\mathrm{Z}=9.69, \mathrm{p}<0.01, \\
\text { highly significant }\end{array}$ \\
\hline $\begin{array}{l}\text { Urine albumin } \\
\text { (gms/24hrs) }\end{array}$ & $2.17 \pm 1.02$ & $13.73 \pm 1.12$ & $\begin{array}{l}\mathrm{Z}=15.54, \mathrm{p}<0.01, \\
\text { highly significant }\end{array}$ \\
\hline
\end{tabular}


In expectant management $20 \%$ treated with Alphamethyldopa, $36 \%$ with Nefidipin and $42 \%$ with both combination drugs and $70 \%$ babies delivered healthy.

Table 5: Antihypertensive used in expectant group with perinatal outcome.

\begin{tabular}{|llllll|} 
Treatment & $\begin{array}{l}\text { Group II } \\
(\text { Expectant) } \\
(\mathbf{n = 5 0 )}\end{array}$ & Perinatal outcome & \\
& No. (\%) & Healthy & FSB & IUD & ND \\
\hline Aldomet & $10(20 \%)$ & 6 & 0 & 1 & 3 \\
\hline Depin & $18(36 \%)$ & 13 & 3 & 2 & 0 \\
\hline Labet & $1(2 \%)$ & 0 & 0 & 0 & 1 \\
\hline $\begin{array}{l}\text { Aldomet+ } \\
\text { Depin }\end{array}$ & $21(42 \%)$ & 16 & 3 & 1 & 1 \\
\hline Total & $\mathbf{5 0}$ & $\mathbf{3 5}$ & $\mathbf{6}$ & $\mathbf{4}$ & $\mathbf{5}$ \\
\hline
\end{tabular}

Table 6: Maternal complications in Group I (aggressive) and Group II (expectant).

\begin{tabular}{|lll|}
\hline $\begin{array}{l}\text { Maternal } \\
\text { complications }\end{array}$ & $\begin{array}{l}\text { Group I } \\
\text { (Aggressive) } \\
(\mathbf{n = 5 0 )}\end{array}$ & $\begin{array}{l}\text { Group II } \\
\text { (Expectant) } \\
(\mathbf{n = 5 0})\end{array}$ \\
\hline Abruption & $5(10 \%)$ & $\mathbf{N o . ( \% )}$ \\
\hline Anhydramnios & $1(2 \%)$ & $4(8 \%)$ \\
\hline Grade 1 retinopathy & $5(10 \%$ & $1(2 \%)$ \\
\hline HELLP & $2(4 \%)$ & $3(14 \%)$ \\
\hline Oligohydramnios & $8(16 \%)$ & $10(20 \%)$ \\
\hline Retinal detachment & $1(2 \%)$ & $1(2 \%)$ \\
\hline Grade 3 retinopathy & $1(2 \%)$ & 0 \\
\hline $\begin{array}{l}\text { Uncontrolled } \\
\text { hypertension }\end{array}$ & 0 & $3(6 \%)$ \\
\hline No complications & $27(54 \%)$ & $21(42 \%)$ \\
\hline Total & $\mathbf{5 0}$ & $\mathbf{5 0}$ \\
\hline
\end{tabular}

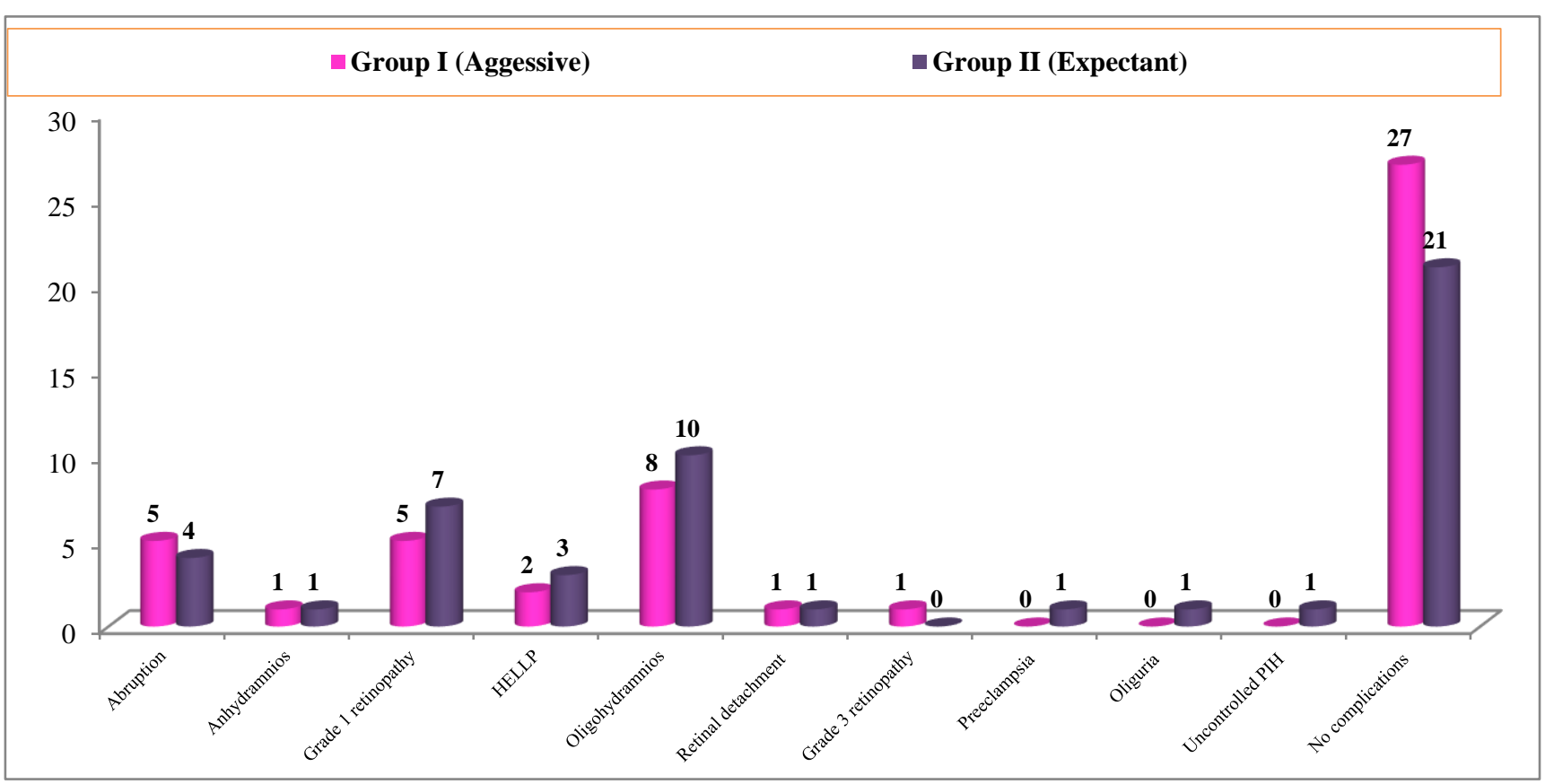

Figure 2: Maternal complications in Group I (aggressive) and Group II (expectant).

Table 7: Type of delivery in Group I (aggressive) and Group II (expectant).

\begin{tabular}{|lll|}
\hline Type of delivery & $\begin{array}{l}\text { Group I } \\
\text { (Aggressive) } \\
(\mathbf{n = 5 0 )}\end{array}$ & $\begin{array}{l}\text { Group II } \\
\text { (Expectant) } \\
(\mathbf{n}=50)\end{array}$ \\
\hline Induced & $33(66 \%)$ & $29(58 \%)$ \\
\hline LSCS & $6(12 \%)$ & $16(32 \%)$ \\
\hline Spontaneous & $11(22 \%)$ & $5(10 \%)$ \\
\hline Total & $\mathbf{5 0}$ & $\mathbf{5 0}$ \\
\hline
\end{tabular}

In group I the complications mentioned here were present at the time of admission. Among these oligohydramnios is the most common, followed by abruption, retinopathy, retinal detachment and HELLP syndrome.

In group II the complications mentioned here were seen at the time of termination of pregnancy. By applying ChiSquare test there is no significant association between various maternal complications in group I and group II $(\mathrm{p}=0.5009)$.

Value of $\mathrm{X}^{2}=7.054$, df $=2$, significant, $\mathrm{p}=0.0294$. 


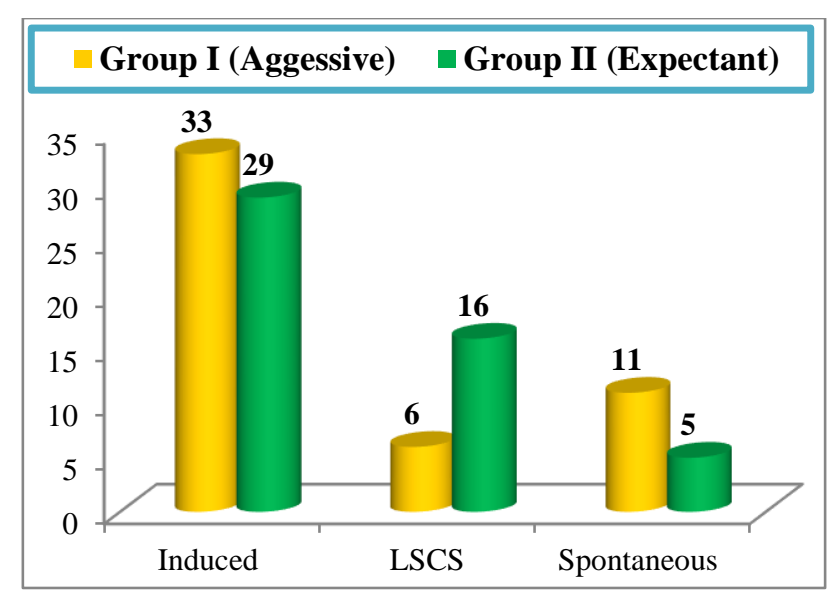

Figure 3: Type of delivery in Group I (aggressive) and Group II (expectant).

By applying Chi-Square test there is a significant association between type of delivery in group I and group II $(\mathrm{p}<0.05)$.

With aggressive intervention $66 \%$ pt's were induced, $12 \%$ pt's were undergone LSCS, $22 \%$ went in spontaneous labour while with expectant management $58 \%$ pt's were induced, $32 \%$ undergone LSCS and $10 \%$ went in spontaneous labour.

Table 8: Hospital stay (in days) in Group I (aggressive) and Group II (expectant).

\begin{tabular}{|lll|}
\hline & $\begin{array}{l}\text { Group I } \\
\text { (Aggressive) } \\
\text { Mean } \pm \text { SD }\end{array}$ & $\begin{array}{l}\text { Group II } \\
\text { (Expectant) } \\
\text { Mean } \pm \text { SD }\end{array}$ \\
\hline Hospital stay in days & $10.98 \pm 5.05$ & $18.70 \pm 7.06$ \\
\hline
\end{tabular}

In aggressive management hospital stay were shorter because of termination of pregnancy within $24 \mathrm{hrs}$ where as in expectant management hospital stay was delayed in view of prolongation of pregnancy.

By applying $\mathrm{Z}$ test of difference between two means there is a significant difference between average hospital saty in days in group I and group II $(\mathrm{p}<0.01)$.

Table 9: Birth weight in Group I (aggressive) and Group II (expectant).

\begin{tabular}{|lll|}
\hline & $\begin{array}{l}\text { Group I } \\
\text { (Aggressive) } \\
(\mathbf{n}=50)\end{array}$ & $\begin{array}{l}\text { Group II } \\
(\text { Expectant }) \\
(\mathbf{n}=50)\end{array}$ \\
\hline Bean \pm SD & Mean \pm SD \\
\hline Birth weight & $1118.08 \pm 328.98$ & $1280.18 \pm 352.10$ \\
\hline
\end{tabular}

By applying $\mathrm{Z}$ test of difference between two sample means there is a highly significant difference between mean values of birth weight in Group I and II $(\mathrm{p}<0.01)$.
Table 10: Perinatal outcome in Group I (aggressive) and Group II (expectant).

\begin{tabular}{|l|l|l|}
\hline Perinatal outcome & $\begin{array}{l}\text { Group I } \\
\text { (Aggressive) } \\
(\mathbf{n = 5 0 )}\end{array}$ & $\begin{array}{l}\text { Group II } \\
\text { (Expectant) } \\
(\mathbf{n = 5 0})\end{array}$ \\
\hline No. $(\%)$ & No. $(\%)$ \\
\hline FSB & $12(24 \%)$ & $5(10 \%)$ \\
\hline IUD & $11(22 \%)$ & $6(12 \%)$ \\
\hline Well and BF & $4(8 \%)$ & $4(8 \%)$ \\
\hline Total & $23(46 \%)$ & $35(70 \%)$ \\
\hline
\end{tabular}

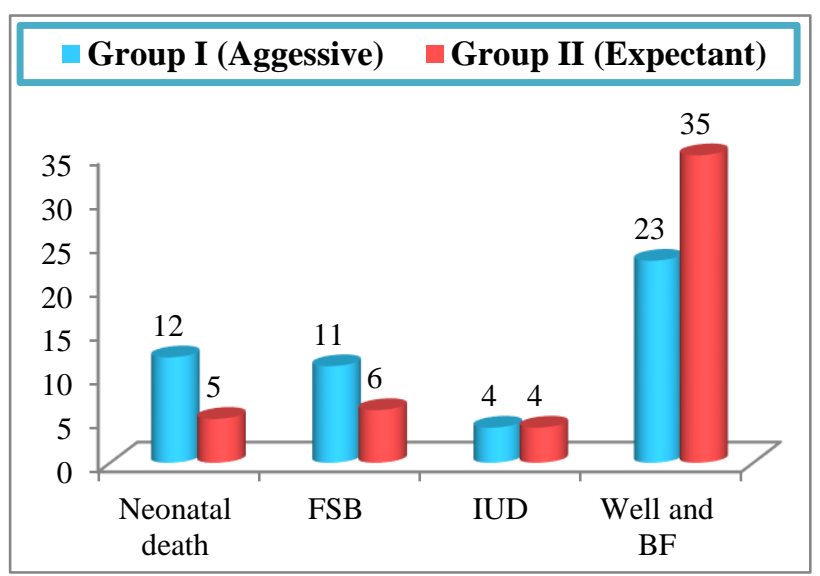

Figure 4: Perinatal outcome in Group I (aggressive) and Group II (expectant)

With aggressive management neonatal deaths, FSB, IUD were observed $24 \%, 22 \%, 8 \%$ respectively while in expectant management it is observed 10\%, 12\%, 8\% respectively.

$46 \%$ babies who received aggressive management were healthy at the time of discharge and $70 \%$ were healthy with expectant management.

Table 11: Causes of neonatal deaths.

\begin{tabular}{|lll|}
\hline Causes & Aggressive & Expectant \\
\hline Ards & $7(58 \%)$ & $2(40 \%)$ \\
\hline Septicemia & $3(25 \%)$ & $2(40 \%)$ \\
\hline Pneumonia & $2(17 \%)$ & $1(20 \%)$ \\
\hline
\end{tabular}

Among all neonatal deaths most of deaths were caused by ARDS and few by Septicemia and Pneumonia.

\section{DISCUSSION}

Hypertensive disorder in pregnancy is a common condition which is responsible for majority of maternal and fetal morbidity and mortality.

$\mathrm{PIH}$ in 24-32 wks as a special group of early onset is associated with high perinatal mortality, lot of work is 
being done to treat patients in this period with expectant line of treatment for better perinatal outcome.

Present study was done at RMC, Loni to evaluate role of expectant line of treatment with view to assess perinatal outcome as compared to control group where aggressive management was done.

Out of total 100 cases in 50 cases pregnancy was prolonged by using expectant line of management and outcome is compared with 50 cases of control group where aggressive management was done.

\section{Gravida score}

Preeclampsia often affects young and nulliparous women so Primigravida are at increased risk for preeclampsia.

Hartikainer at all in 1998, Stamilio et all in 2000 conducted various studies. ${ }^{3,4}$ Studies support that Primigravida are at increased risk than multigravidas. This could be due to exposure to chorionic Villi for the first time. ${ }^{5}$ In another study conducted by Haddad in, $55 \%$ were Primigravida. ${ }^{6}$

Duckitt and Harrington also conducted a study that also supported that Primigravida are more at risk for developing preeclampsia. $^{7}$

In the present study $53 \%$ of patients were Primigravida and the remaining $47 \%$ were multigravidas. After applying chi square test no significant association is seen in gravida score of the two groups.

\section{Gestational age}

Pregnancy between gestational age 24 to 32 weeks is termed as early onset pregnancy induced hypertension.

In the present study total 100 cases of early onset pregnancy induced hypertension are taken, out of which in 50 cases, who presented with deranged PIH profile or with uncontrolled hypertension, pregnancy was terminated within $24 \mathrm{hrs}$ and such patients were kept under aggressive management, and the rest 50 cases with normal PIH profile were given expectant line of management to prolong pregnancy. Of the total patients kept in each group, patients were divided into two categories depending on gestational age. The first group contains from 24 to 28 weeks and the second contain from 29 to 32 weeks.

Symptoms of pregnancy induced hypertension include edema, nausea, vomiting, blurring of vision.

$6 \%$ of women presented in this study with multiple symptoms that include nausea, blurring of vision and ascitis. $17 \%$ of patients have no symptom at the time of admission, out of which $5 \%$ belong to aggressive group and $12 \%$ belong to expectant group. ${ }^{8}$
Table 12: Symptoms of pregnancy induced hypertension.

\begin{tabular}{|llll|}
\hline Symptoms & Present study \\
\hline Edema & $86 \%$ & $\begin{array}{l}\text { Aggressive } \\
\text { group }\end{array}$ & $\begin{array}{l}\text { Expectant } \\
\text { group }\end{array}$ \\
\hline Nausea & $22 \%$ & $72 \%$ & $74 \%$ \\
\hline $\begin{array}{l}\text { Visual } \\
\text { changes }\end{array}$ & $15 \%$ & $2 \%$ & $2 \%$ \\
\hline Oligouria & $10 \%$ & $2 \%$ & 0 \\
\hline
\end{tabular}

\section{Investigations}

Patients with deranged profile were kept in aggressive group.

The mean of serum uric acid levels in aggressive is 7.9 $\mathrm{mg} \%$ and mean in expectant group is $5.6 \mathrm{mg} \%$. Mean of platelet count in aggressive group is 1,02,250/cumm and expectant group is $1,82,979 /$ cumm. Mean of prothrombin time in aggressive group is 17.6 and expectant group is 13.7. Mean of urine albumin ( $\mathrm{gm} / 24 \mathrm{hrs})$ in aggressive group is 2.17 and expectant group is 2.59 .

Patients who were kept under expectant management are managed on antihypertensive Aldomet/calcium channel blockers or labetalol and decision of termination of pregnancy was made on either uncontrolled hypertension, with premonitory symptoms or a deranged profile, thrombocytopenia<70000/cumm, abruption or fetal distress.

\section{Treatment}

In the present study $36 \%$ of patients were treated with nifedipine, $72 \%$ of them had healthy babies, $16 \%$ had FSB while $11 \%$ had IUD.

In a study conducted by Sibai et all,100 patients were given nifedipine of them pregnancy was prolonged for around 22 days and no neonatal death occurred in them. ${ }^{9}$

$2 \%$ of the patients treated with labetalol of which no maternal complication occurred but all of them had neonatal death, In a study conducted by Pickles et all in 1992 in which labetalol was studied on 70 patients and pregnancy was prolonged 26 days with no neonatal death. ${ }^{10}$

In The present study Methyldopa was also given and found to be effective. $20 \%$ of patients treated with methyldopa of which $60 \%$ had healthy babies, $30 \%$ had neonatal death and $10 \%$ had IUD.

Abha Singh extensively studied drug Methyldopa, with seven years of follow-up of the babies. It was found to be very safe for the fetus. ${ }^{11}$ 
In the present study $42 \%$ of patients were given two drugs to control hypertension, out of them $76 \%$ had healthy babies, $14 \%$ had FSB, $4 \%$ had IUD while $4 \%$ had neonatal death.

\section{Maternal complications}

In the present study, oligohydramnios occurred in $18 \%$ of patients, and $9 \%$ of patients developed abruption of placenta, HEELP syndrome was seen in $5 \%$ of patients.

In a study conducted by visser and wallenburg on 254 cases of early onset pregnancy induced hypertension, abruption occurred in $5 \%$ of patients while HEELP syndrome was seen in $9 \%$ of patients. ${ }^{12}$

Kaur Amrit Pal, Saini AS had reported an incidence of $4 \%$ for HELLP syndrome. ${ }^{13}$

Other studies have reported the following incidences: ${ }^{14-16}$

- B Hadd ad - $17 \%$,

- J Rose et al - $22.87 \%$,

- Girija, Umadevi - $1.2 \%$

While $2 \%$ of patients developed retinal detachment and other complications like hypertensive retinopathy was seen in $13 \%$ of the patients. There is no significant association seen between the complications seen in aggressive and expectant group.

A comparison of major maternal morbidity associated with management of preeclampsia by different studies and our observation of women with severe preeclampsia remote from term gestation.

The development of maternal complications in expectant group leads to termination of pregnancy.

\section{Gestational age at delivery}

In expectant management, the pregnancy was prolonged by giving antihypertensive agents and was terminated in case of uncontrolled hypertension or any other fetal and maternal complication.

Out of the 50 patients kept in expectant management those who were below 28 weeks, $80 \%$ of them could not complete even 1 week and pregnancy was terminated at around $5^{\text {th }}$ day, but for patients above 28 weeks' expectant management showed good results.

So it can be said that expectant management is useful in patients beyond 28 weeks.

Table 13: Gestational age and associated major maternal morbidity in different studies.

\begin{tabular}{|c|c|c|c|c|c|c|}
\hline Treatment & & & Gestational & Patients & Major maternal & Death \\
\hline mode & Study & Year & age (wk) & (n) & morbidity (n) & (n) \\
\hline \multirow{2}{*}{ Delivery } & Sibai et al ${ }^{17}$ & 1990 & $<25$ & 10 & None & 0 \\
\hline & Olah et al $^{18}$ & 1993 & $24-32$ & 28 & None & 0 \\
\hline \multirow{6}{*}{ Observation } & \multirow{6}{*}{ Sibai et al $^{19}$} & \multirow{6}{*}{1986} & \multirow{6}{*}{$18-27$} & \multirow{6}{*}{60} & Abruptio placentae (13) & 0 \\
\hline & & & & & Eclampsia (10) & \\
\hline & & & & & $\operatorname{HELLP} *(10)$ & \\
\hline & & & & & Acute renal failure (3) & \\
\hline & & & & & Hypertensive encephalopathy (2) & \\
\hline & & & & & Intracerebral hemorrhage (1) & \\
\hline & \multirow[t]{2}{*}{ Sibai et al ${ }^{17}$} & \multirow[t]{2}{*}{1990} & \multirow[t]{2}{*}{$<25$} & \multirow[t]{2}{*}{15} & $\begin{array}{l}\text { Ruptured hepatic hematoma (1) } \\
\text { Abruptio placentae (2) }\end{array}$ & 0 \\
\hline & & & & & Eclampsia (1) & \\
\hline & \multirow{3}{*}{$\begin{array}{l}\text { Moodley et } \mathrm{al}^{20} \\
\text { Olah et } \mathrm{al}^{18}\end{array}$} & \multirow{3}{*}{$\begin{array}{l}1993 \\
1993\end{array}$} & \multirow{3}{*}{$<2624-32$} & \multirow{3}{*}{1228} & $\begin{array}{l}\text { HELLP (3) Abruptio placentae (1) } \\
\text { Acute renal failure (1) }\end{array}$ & 10 \\
\hline & & & & & Pulmonary edema (1) & \\
\hline & & & & & HELLP variant (4) & \\
\hline & \multirow{4}{*}{$\begin{array}{l}\text { Visser and } \\
\text { Wallenburg }^{12}\end{array}$} & \multirow{4}{*}{1995} & \multirow{4}{*}{$<32$} & \multirow{4}{*}{254} & $\begin{array}{l}\text { Acute renal failure (1) Abruptio } \\
\text { placentae (13) }\end{array}$ & 0 \\
\hline & & & & & Eclampsia (1) & \\
\hline & & & & & HELLP (24) & \\
\hline & & & & & Pulmonary edema (4) & \\
\hline & Pattinson et $\mathrm{al}^{21}$ & 1988 & $<28$ & 45 & $\begin{array}{l}\text { Hemorrhagic complications (15) } \\
\text { Abruptio placentae (1) }\end{array}$ & 0 \\
\hline & \multirow{3}{*}{ Odendaal et $\mathrm{al}^{22}$} & \multirow{3}{*}{1987} & \multirow{3}{*}{$<34$} & \multirow{3}{*}{129} & $\begin{array}{l}\text { Pulmonary edema (3) Abruptio } \\
\text { placentae }\end{array}$ & 0 \\
\hline & & & & & HELLP & \\
\hline & & & & & Acute renal failure & \\
\hline
\end{tabular}


Table 14: Gestational age and associated major maternal morbidity in different studies.

\begin{tabular}{|llll|}
\hline Delivery (aggressive management) & $<28$ & 14 & $\begin{array}{l}\text { Abruptio placenta(2) } \\
\text { Hypertensive retinopathy(2) } \\
\text { Oligohydramnios(3) }\end{array}$ \\
& & & $\begin{array}{l}\text { Abruptio placenta(3) } \\
\text { HEELP(2) }\end{array}$ \\
& $28-32$ & 36 & $\begin{array}{l}\text { Hypertensive retinopathy(4) } \\
\text { Oligohydramnios(5) } \\
\text { Retinal detachment(1) }\end{array}$ \\
\hline Observation (expectant management) & $<28$ & 5 & $\begin{array}{l}\text { Abruption(2) } \\
\text { Hypertensive retinopathy(1) }\end{array}$ \\
\hline & $28-32$ & 45 & $\begin{array}{l}\text { Abruptio placenta(2) } \\
\text { HEELP(3) } \\
\text { Hypertensive retinopathy(6) }\end{array}$ \\
\hline
\end{tabular}

Table 15: Positive Foetal outcome in present study.

\begin{tabular}{|lll|}
\hline Management & LSCS & Foetal outcome \\
\hline Aggressive & $6 \%$ & $83 \%$ \\
\hline Expectant & $16 \%$ & $93 \%$ \\
\hline
\end{tabular}

Several studies are conducted which show that as the gestational age increases fetal outcome improves.

Jenkins conducted a study and found the fetal survival was just $10 \%$ in pregnancies $<27$ weeks. ${ }^{23}$

Ingrid PM conducted a study which also supported this. ${ }^{24}$

Pattinson 21 conducted a study in which patients with gestational age $<24$ weeks perinatal mortality was $100 \%$ while in patients with gestaional age of 25-28 weeks perinatal mortality was $71 \%$.

Type of delivery

Iqbal et al reported incidence of CS as $43 \%$ and vaginal as $57 \%$.

Table 16: Comparison of mode of delivery with present study.

\begin{tabular}{|lll|}
\hline Study & LSCS & Vaginal delivery \\
\hline Iqbal in 1996 & $43 \%$ & $57 \%$ \\
\hline M.R. Datta & $55 \%$ & $45 \%$ \\
\hline Present study & $22 \%$ & $78 \%$ \\
\hline
\end{tabular}

In another study by M.R. Datta, Luna Pant, $45 \%$ were vaginal deliveries and caesarean section rate was $62 \%$; Labour induction was required in 64 cases $(54.7 \%)$ whereas in the present study, $22 \%$ of patients underwent LSCS out of which $16 \%$ belong to expectant group. $78 \%$ of women delivered vaginally out of them, $62 \%$ of patients were induced. All $22 \%$ of LSCS were done at gestational age $>28$ weeks.

\section{Fetal outcome}

\section{Fetal complications}

All the delivery was conducted before 36 weeks so all the babies were preterm, of which in $50 \%$ of the babies the complication was only preterm, $43 \%$ of babies had Intra Uterine Growth Retardation in the present study.

In another study conducted on mid trimester pregnancy induced hypertension by P. Vigil IUGR accounts for $17 \%$ of the total live births. ${ }^{25}$

In another study conducted by Bassam Hadaad6 in 2004 on mid trimester pregnancy induced hypertension, IUGR accounts for $27 \%$ of cases.

\section{Perinatal mortality}

Table 17: Perinatal mortality in present study.

\begin{tabular}{|llll|l|}
\hline Management & FSB & IUD & $\begin{array}{l}\text { Neonatal } \\
\text { deaths }\end{array}$ & $\begin{array}{l}\text { Perinatal } \\
\text { mortality }\end{array}$ \\
\hline Aggressive & $22 \%$ & $8 \%$ & $24 \%$ & $54 \%$ \\
\hline Expectant & $12 \%$ & $8 \%$ & $10 \%$ & $30 \%$ \\
\hline
\end{tabular}

In the present perinatal mortality was high in aggressive group where pregnancy was terminated within $24 \mathrm{hrs}$, while in expectant group where pregnancy was continued the perinatal mortality was $30 \%$.

In a study conducted by David R Hall on the outcome of expectant line of management of early onset pregnancy induced hypertension perinatal mortality was around $39 \% .^{26}$

$46 \%$ of patients in aggressive group the babies were healthy and $70 \%$ of patients in expectant group had healthy babies at the time of discharge. 


\section{Birth weight}

Birth weight depends on the gestational age, although by giving expectant line if management we have tried to prolong the pregnancy but the mean birth weight in two groups are in aggressive group it is 1118 and in expectant group the mean weight is 1280 gms. this difference is statistically significant. So birth weight of the baby improved with expectant line of management.

In a study conducted by Charl Oettle, the perinatal mortality rate in babies $>1000$ gms. was $2.3 \%$ and the perinatal mortality rate in babies $>500-1000$ gms was $3.7 \% .^{27}$

In the present study, in aggressive management PNMR with birth weight between 500 to 1000 gms was $100 \%$ : as the birth weight increased fetal survival rate also increases and birth weight between 1201-1400 the fetal survival rate was $88 \%$.

In expectant management, birth weight between 5001000 gms fetal survival rate was $12 \%$ while in birth weight between 1201 to 1400 the survival rate was $81 \%$ while in birth weight between 1401 to 1600 the survival rate is $100 \%$.

\section{Neonatal deaths}

Total $17 \%$ of death occur in neonatal period. $12 \%$ of which occurred in aggressive group and 5\% in expectant group.

Table 18: Causes of neonatal death.

\begin{tabular}{|llll|}
\begin{tabular}{|l} 
Neonatal \\
death
\end{tabular} & $\begin{array}{l}\text { David } \\
\text { R Hall } \\
\text { in 2001 }\end{array}$ & $\begin{array}{l}\text { Present study } \\
\text { (Aggressive } \\
\text { management) } \\
n=12\end{array}$ & $\begin{array}{l}\text { Present study } \\
\text { (Expectant } \\
\text { management) } \\
\mathrm{n}=5\end{array}$ \\
\hline ARDS & $40 \%$ & $58 \%$ & $40 \%$ \\
\hline Septicemia & $25 \%$ & $25 \%$ & $40 \%$ \\
\hline Pneumonia & $20 \%$ & $17 \%$ & $20 \%$ \\
\hline
\end{tabular}

Septicemia and ARDS are the two major cause of neonatal death in this study. ${ }^{26}$

Hospital stay in days- In patients who received aggressive line of management- Termination of pregnancy was done in 24 hrs but in expectant line of management, pregnancy has been prolonged and thus hospital stay also becomes more with a mean of 11 days in aggressive and 19 days in expectant management.

In this study of early onset pregnancy induced hypertension $70 \%$ of patients in expectant group had good fetal outcome at the time of discharge. But patients who belong to gestational age between 24-28 weeks and were given expectant line of management, $80 \%$ of them pregnancy could not be continued beyond 28 weeks, patients between 28-32 weeks on expectant management showed good outcome.

Maternal complications of the two groups when compared proved to be not significant; so expectant line of management showed good results in patients between 28-32 weeks.

A study done by Ingrid P.M. Gaugler-Senden concluded that Early onset preeclampsia with an onset before 24 weeks gestation, results in considerable maternal and perinatal morbidity and mortality. ${ }^{24}$

Therefore, expectant management should not be considered as a routine treatment option in these patients. But Expectant management of severe preeclampsia at 24 to 32 weeks in a tertiary care center is associated with good perinatal outcome with a minimal risk for the mother.

\section{CONCLUSION}

Though the incidence of preeclampsia is on the decline, still it remains the major contributor to poor maternal and fetal outcome.

In preeclampsia, pathology should be understood as it involves multi-organ dysfunction. With regular antenatal visits and proper counselling preeclampsia can be diagnosed early and managed.

Full term pregnancy should be terminated while early onset pregnancy induced hypertension the decision of expectant management can be taken if all other parameters are normal.

Expectant management in patients with gestational age $>28$ weeks gives good fetal outcome. Preterm, Intra Uterine Growth Retardation are the main complications seen, besides this septicemia and ARDS accounts for $87 \%$ of cause for neonatal deaths. In case of early onset pregnancy induced hypertension with the use of antihypertensive drugs and proper monitoring pregnancy can be prolonged, but in case of any deranged $\mathrm{PIH}$ profile or uncontrolled hypertension the decision of terminating the pregnancy should be taken. Patients should be treated in a tertiary care center with proper NICU facility for baby.

\section{ACKNOWLEDGMENTS}

The author would like to thank all other staff members of the Department of Obstetrics and Gynaecology, RMC for their kind support, cooperation and guidance.

Funding: No funding sources

Conflict of interest: None declared

Ethical approval: The study was approved by the Institutional Ethics Committee 


\section{REFERENCES}

1. Sibai BM, Mercer BM, Sciff E. Aggressive vs expectant management of severe preeclampsia at 28 to 32 weeks gestation. A randomized controlled trial. Am J Obstet Gynaeco. 171:818.

2. Barber D, Xing G, Towner D. Expectant management of severe eclampsia between 24-32 weeks gestation: A ten year review. Abstract No 742. Presented at the $29^{\text {th }}$ Annual Meeting of the Society for Maternal-Fetal Medicine; 2009:26-31.

3. Hartikainen A, Aliharmi RH. A cohort study of epidemiological associations and outcomes of pregnancies with hypertensive disorders. Hypertension in pregnancy. 2009;17:31-41.

4. Stamilio DM, Sehdev HM, Morgan MA, Propert K, Macones GA. Can antenatal clinical and biochemical markers predict the development of severe preeclampsia? American journal of Obstetrics and Gynaecology. 2000;182:589-94.

5. Dekker GA, Sibai BM. Etiology and pathogenesis of preeclampsia: Current concepts. American Journal of Obstetrics and Gynaecology. 1998;179:1359-75.

6. Haddad B, Deis S, Goffinet F. Maternal and perinatal outcomes during expectant management of 239 preeclamptic women between 24 and 33 weeks' gestation. Am J Obstet Gynecol. 2004;190(6):1590.

7. Duckitt, Harrington; BMJ. 2005 Mar;330(7491):565.

8. Khan H. Peculiar risk factors and complications of pregnancy induced hypertension in a tertiary care hospital of Peshawar, Pakistan Armed Forces Medical Journal, September. 2009;4:2-4.

9. Sibai BM, Barton JR, Akl S. A randomized prospective comparison of nifedipine and bed rest versus bed rest alone in the management of preeclampsia remote from term. Am J Obstet Gynecol. 1992;167(1):879.

10. Pickles CJ, Broughton Pipkin F, Symonds EM. A randomised placebo controlled trial of labetalol in the treatment of mild to moderate pregnancy induced hypertension. $\mathrm{Br} \quad \mathrm{J}$ Obstet Gynaecol. 1992:99(12):964.

11. Singh A, Verma R. Choice of antihypertnesive agents in PIH. Obs and Gynae. 2003;7:57-61.

12. Visser, Wallenberg. Maternal and perinatal outcome of temporizing management in 254 consecutive patients with severe preeclampsia remote from term. Eur J Obstet Gynaecol Reprod Biol. 1995:63(2):14754.

13. Pal AK, Saini AS, Dhillon SPS. HELLP Syndrome associated with moderate to severe pre-eclampsia / eclampsia. J Obstet Gyndecol India. 2003;53(2):1659.

14. Haddad B, Barton JR, Livingston JC. Risk factors for adverse maternal outcomes among women with
HELLP (hemolysis, elevated liver enzymes, and low platelet count) syndrome. Am J Obstet Gynecol. 2000; $183: 444$.

15. Rose J. Maternal and periantal outcome associated with the syndrome of hemolysis, elevated liver enzymes and low platelets in pre-eclampsia / eclampsia. J Obstet Gynecol Ind. 2004;54(2):147-50.

16. Girija, Devi U, Udaya R. Unusual accompaniments of pregnancy induced hypertension. Journal of Obst and Gynae of India. 2001;51(6):69-70.

17. Sibai BM. Am J Obstet Gynaecol: 1990;163(3):7338.

18. Olah KS, Redman CW, Gee H. Management of severe, early preeclampsia: is conservative management justified Eur J Obstet Gynecol Reprod Biol. 1993;51:175-80.

19. Sibai BM, El-Nazer A, Gonzalez-Ruiz A. Severe preeclampsia-eclampsia in young primigravid women: Subsequent pregnancy outcome and remote prognosis. Am J Obstet Gynecol. 1986;155:1011.

20. Moodley J, Koranteng SA. Expectant management of early onset of severe preeclampsia in Durban. S Afr Med. J. 1993:83(8):584-7.

21. Pattinson RC. Conservative management of severe proteinuric hypertension before 28 weeks gestation. S Afr Med J. 1988;73:516-8.

22. Odendaal HJ. Frequent fetal heart rate monitoring for early detection of abruptio placentae in severe proteinuric hypertension. S Afr Med J. 1988:74:1921.

23. Jenkins SM, Head BB, Hauth JC. Severe preeclampsia at $<25$ weeks of gestation: Maternal and neonatal outcomes. Am J Obstet Gynecol. 2002; $186: 790$.

24. Ingrid PM, Senden G, Annemarie GH, Visser W, Eric AP, Christanne JM. Maternal and perinatal outcome of preeclampsia with an onset before 24 weeks gestation: Audit in a tertiary referral center, European journal of Obstetrics and Gynaecology and Reproductive Biology. 2006;128(1):216-21.

25. Vigil-De Gracia P, Montufar-Rueda C, Ruiz J. Expectant management of severe preeclampsia and preeclampsia superimposed on chronic hypertension between 24 and 34 weeks' gestation. Eur J Obstet Gynecol Reprod Biol. 2003;107:24.

26. Hall DR, Odendaal HJ, Steyn DW. Expectant management of severe pre-eclampsia in the midtrimester. Eur J Obstet Gynecol Reprod Biol. 2001:96(2):168.

27. Oettle C, Hall D, Roux A. Early onset severe preeclampsia: Expectant management at a secondary hospital in close association with a tertiary institution. BJOG Jan. 2005;112:84-8.

Cite this article as: Mandade K, Singh K, Bhavthankar D Outcome of expectant line of management in early onset (24-32weeks) pregnancy induced hypertensions. Int J Reprod Contracept Obstet Gynecol 2017;6:1932-41. 